Fulton, F. (1960). J. gen. Microbiol. 22, 416-422

\title{
Tissue Culture on Polythene
}

\author{
By F. FULTON \\ London School of Hygiene and Tropical Medicine, Keppel Street, \\ London, W.C. 1
}

SUMMARY: Fragments of solid organs can be squashed, without destroying the viability of the cells, to form a thin sheet of cells which is stuck to polythene film with clotted mouse plasma. The film conveniently floats on a simple culture medium in which embryonic tissues multiply within $24 \mathrm{hr}$. and adult tissues survive for several days. The tissue on the polythene is thin enough to mount on a microscope slide and examine with phase-contrast illumination and an oil-immersion objective; alternatively, since the polythene is inert to most organic solvents, the tissue can be stained and mounted, using standard histological techniques. The squashed tissue on polythene is more readily infected by viruses and more easily examined than are fragments of tissue embedded in plasma on a coverglass. The method was used to study one virus cytopathogenic for many chick tissues and another virus detected by the haemadsorption phenomenon.

Pieces of thin membranes have been used for the cultivation of a number of viruses (Fulton \& Armitage, 1951; Fazekas de St Groth \& White, 1958); these techniques depend on the arrangement of the susceptible cells on the surfaces of the membrane, and so pieces of solid organs cannot be used in the same way. However, with a thin sheet of polythene as a supporting structure, fragments of solid organs can be squashed so that the cells remain viable and the tissue is reduced in most places to the thickness of one cell; everywhere the squashed tissue is so thin that the cells can be observed under the microscope with a $1.6 \mathrm{~mm}$. objective. The architecture of the tissue is maintained and therefore the cells can be recognized. If the solid organs are obtained from embryos, multiplication of the cells in the implanted fragments occurs within $24 \mathrm{hr}$. in a very simple fluid medium, and many of these new cells grow out from the fragments in a single layer. This technique has been applied to the culture of fragments of organs obtained from chick embryos, and the effect of two viruses on these tissues is described.

An earlier version of this technique was shown elsewhere (Fulton, 1958).

\section{METHODS}

Apparatus. The tissue culture tray was made from a glass Petri dish with a base diameter of $13.75 \mathrm{~cm}$. and a depth of $1.5 \mathrm{~cm}$. On to the base, sixteen short lengths of glass tubing were sealed by fusion, to form cups. The glass cylinders had an internal diameter of $1.375 \mathrm{~cm}$. and an external diameter of $1.75 \mathrm{~cm}$., and they were $0.75 \mathrm{~cm}$. long. The sixteen cylinders were arranged in four rows of four (Pl. 1, fig. 1a). In making the culture tray, a piece of asbestos sheet was cut to fit the inside of the base of the Petri dish; the sheet was drilled with 
sixteen holes, arranged as described, to hold the glass cylinders. In this way the cylinders were kept in place while the base of the Petri dish was heated, annealed and cooled.

For use, the tray, with its lid, was sterilized in a hot-air oven at $160^{\circ}$ for $\frac{1}{2} \mathrm{hr}$. Although convenient, these tissue culture trays are not an essential part of the technique: it is possible to use, instead, arrays of small test tubes, or a sterilizable plastic tray.

Polythene of the thinnest gauge was used, with a thickness of $0.00375 \mathrm{~cm}$. (Alkathine brand of polythene film, I.C.I., Welwyn Garden City, Hertfordshire. From sheets of this polythene, disks with a diameter of $1.25 \mathrm{~cm}$. were cut with a metal punch intended for stamping leather. The polythene was laid flat on a sheet of hardboard, the punch was held firmly in place and the top of it was struck with a wooden mallet. Just before use, the disks of polythene were cleaned and sterilized by immersing them in ether (Analytical grade). After a few minutes, the disks were removed with sterile forceps to a sterile Petri dish with the lid left ajar so that the ether could escape. At this stage the polythene curled up, but as soon as the last trace of ether had evaporated, the disks lay flat and were ready for use (Pl. 1, fig. $1 b$ ).

The plate for squashing the tissue was a sheet of Perspex $12.5 \mathrm{~cm}$. square and $0.625 \mathrm{~cm}$. thick; a glass plate could not be used because a non-wetting surface was required. The Perspex was ruled centrally with a grid of sixteen squares, $2.5 \mathrm{~cm} .{ }^{2}$, arranged in four rows of four, to match the design of the tissue-culture tray (Pl. 1, fig. 2). Before use, the plate was sterilized by exposure to ultraviolet radiation. After use, it was washed in water, dried and polished with a fine cloth; the Perspex should not be scratched except where the grid is ruled. When it was necessary to remove grease from the Perspex, hexane did not harm the surface. When using the plate it was convenient to lay it on a black background.

Reagents. Medium for tissue culture.

Stock solution: $\mathrm{Na}_{2} \mathrm{HPO}_{4}, \mathbf{0 . 2 3 7}$ g., $\mathrm{KH}_{2} \mathrm{PO}_{4}, \mathbf{0 . 2 2 7}$ g.; $\mathrm{MgSO}_{4} .7 \mathrm{H}_{2} \mathrm{O}$, 0.200 g.; glucose, $1 \cdot 0$ g.; tryptone (Oxo Ltd., London), 1.0 g.; glass-distilled water, $50 \mathrm{ml}$. This stock solution ( $\mathrm{pH} 6 \cdot 8)$ was sterilized by filtration through an Oxoid membrane filter (Oxo Ltd., London), and stored at $4^{\circ}$. For use, the stock solution was diluted $1 / 20$ in a sterile solution of $0.8 \%(\mathrm{w} / \mathrm{v}) \mathrm{NaCl}$ in glass-distilled water; usually 20 units penicillin $/ \mathrm{ml}$. were added to the final solution. The concentrations of the phosphate buffer, the magnesium salt and the tryptone were all quite critical within a factor of 2. Some glucose was essential, but its concentration could be varied over a wide range with little apparent effect. The use of phosphate instead of bicarbonate as a buffering system made it unnecessary to seal the tissue culture tray.

Calcium chloride: $2 \%(\mathrm{w} / \mathrm{v})$ in glass-distilled water, sterilized by filtration through an Oxoid membrane filter, and stored at $4^{\circ}$.

Fresh citrated mouse plasma: this was obtained just before it was required and one mouse provided ample plasma for perhaps 100 polythene disks. A mouse was anaesthetized with ether and blood was removed from the heart and mixed immediately with an equal volume of sterile Alsever's solution 
(Bukantz, Rein \& Kent, 1946). The blood cells were deposited by centrifugation and the clear plasma removed. The plasma should be quite colourless; a faint tinge of haemoglobin indicates some clotting and such plasma will clot too rapidly. Heparinized fowl plasma was not suitable, for it did not clot with sufficient regularity nor at the right time, with this technique.

Technique for squashing tissue fragments. A small piece of tissue, for example a lobe of the lung from a chick embryo, 11-16 days old, was transferred to a sterile Petri dish and cut into fragments by using two small scalpels with a scissor-like motion; it is difficult to cut the fragments too small. After cutting, the fragments were kept moist in a few drops of the culture medium.

In another sterile Petri dish, a large drop ( $0 \cdot 1 \mathrm{ml}$.) of mouse plasma was placed next to a smaller drop $(0.02 \mathrm{ml}$.) of $2 \%$ calcium chloride; when later the drops were mixed, the final concentration of calcium chloride in the plasma was about $0.3 \%(w / v)$.

With the sterile Perspex plate on a black background, a very small drop $(0.004 \mathrm{ml}$.) of the lung fragments in culture medium was placed quickly in each of the sixteen squares. The drops of mouse plasma and calcium chloride were at once mixed with a sterile mounted needle; the plasma did not clot for at least $5 \mathrm{~min}$. and this gave time for the next step.

A sterile polythene disk, held at the edge with fine forceps, was uniformly wetted on one surface with the drop of calcified plasma but the other surface was kept dry. The disk was now placed on the lung fragments in one square of the Perspex plate, with the dry side uppermost. The fragments in the remaining squares were rapidly treated similarly. The plate was turned over on to sterile blotting paper resting on a flat surface, and pressed firmly so as to express most of the fluid from under the disks. The force needed depended on the particular tissue, but the effect could be observed through the Perspex.

The plate was now turned over so that the polythene disks again lay uppermost (Pl. 1, fig. 2), and covered with another sterile blotting paper until the plasma drop, remaining in the Petri dish, had clotted (5-10 min. from the time of mixing). Meanwhile $0.5 \mathrm{ml}$. of culture medium was added to each cup of the tissue culture tray. As soon as the plasma had clotted, a drop of sterile physiological saline was placed on the Perspex near the edge of each polythene disk; the drop must not run over the dry polythene. With a quick circular movement of the tip of the fine forceps under the edge of the disk, the drop of saline was allowed to run under the polythene so that the disk billowed up. Most of the tissue remained firmly fixed to the disk, though the amount varied with the type of tissue; always, however, enough stayed on the polythene if the plasma had clotted. As each polythene disk was floated on the drop of saline, it was placed in one of the cups in the tissue culture tray with the dry surface uppermost and the tissue layer floating on the medium.

Other tissues have been squashed and cultured in the same way, for example muscle, skin, brain, intestine, kidney, spleen and foetal membranes from chick or mouse embryos. Embryo liver was difficult to culture because the tissue was too soft and few cells survived. Tissues from adult animals could 
also be squashed and cultured, but as no outgrowth occurred in a few days from the implanted fragments, their viability was judged by their histological appearance. Many squashed tissues from adult mice seemed to retain their fresh appearance for at least 4 days in the simple medium described.

Examination of the squashed tissue microscopically. The polythene disk was laid, tissue up, on a drop of saline on a microscope slide, and covered with a drop of glycerol and a coverglass. The tissue was examined with phasecontrast illumination using a $10 \mathrm{~mm}$. or a $4 \mathrm{~mm}$. objective. Alternatively, the polythene disk was floated tissue down on a solution of $5 \%(\mathrm{w} / \mathrm{v})$ iron alum: $\mathrm{Fe}_{2}\left(\mathrm{SO}_{4}\right)_{3}\left(\mathrm{NH}_{4}\right)_{2} \mathrm{SO}_{4} \cdot 24 \mathrm{H}_{2} \mathrm{O}$. For this staining procedure it was convenient to use the Perspex trays distributed by W.H.O. for haemagglutination tests (Expert Committee on Influenza, 1953). After 5 min. the disk was transferred, without washing, to float in another cup containing Heidenhain's haematoxylin (Lillie, 1954). As is customary with this staining method, the tissue was overstained, then washed gently in a beaker of water, and differentiated by returning it to float on the iron alum solution until the tissue was a grey colour and the plasma quite colourless. The disk was washed again in water, drained on blotting paper and dropped into a small test-tube containing acetone. After about $5 \mathrm{~min}$. it was transferred to a test-tube containing xylene and, when clear, it was mounted in neutral balsam, with the tissue uppermost, under a coverglass. These stained preparations were also viewed under the microscope with phase-contrast illumination; they revealed very fine cellular detail when examined with a $1.6 \mathrm{~mm}$. objective.

\section{RESULTS}

The growth of embryonic tissues. Plate 2, fig. 3, shows a fragment of chick lung on a polythene disk immediately after implantation, examined under the microscope with a $10 \mathrm{~mm}$. objective and phase-contrast illumination. Plate 2, fig. 4, shows a lung fragment from a chick embryo implanted on polythene, cultured for $48 \mathrm{hr}$. at $37^{\circ}$ in the medium described and then examined with a $10 \mathrm{~mm}$. objective. Plate 2, fig. 5, shows a similar preparation stained with ironhaematoxylin and examined with a $1.6 \mathrm{~mm}$. objective; many mitotic figures were found, and for many purposes the outgrowth obtained in $24 \mathrm{hr}$. was sufficient. Good growth was also obtained in 24-48 hr. from other embryonic tissues; for example, sheets of epithelium were obtained from fragments of chick intestine.

The effect of Semliki forest virus on chick embryo tissues. The virus was introduced into the cup immediately the polythene disk, with the squashed tissue, had been floated on to the medium, that is, before any growth had occurred. The virus dilution was added to the cup by allowing a $0.02 \mathrm{ml}$. drop from a calibrated dropping pipette to fall between the edge of the disk and the wall of the cup. Plate 2, fig. 6, shows the effect on chick lung after $48 \mathrm{hr}$. incubation, of an inoculum into the cup, of $0.02 \mathrm{ml}$. of a $10^{-4}$ dilution of a mouse brain suspension of Semliki forest virus. The end-point of such a titration was usually about $10^{-7}$ which was the same end-point obtained by titrating the virus 
intracerebrally in groups of mice. This suggested that, after squashing, the plasma layer was so thin that virus had easy access to the susceptible cells. The cytopathic effect could be prevented by adding to the cup, before the virus, an appropriate amount of specific immune serum obtained from a guinea pig. A similar cytopathic effect was obtained on chick muscle, but there was little visible effect on chick intestinal epithelium.

The effect of a strain of influenza virus on chick embryo lung. Chick allantoic fluid containing the PR8 strain of influenza $A$ virus was diluted $10^{-2}$, and $0.02 \mathrm{ml}$. drops of this dilution were added to cups containing disks of freshly implanted chick lung. The tissue grew during the subsequent $48 \mathrm{hr}$. incubation, in much the same way as in the controls without virus, but virus multiplication could be demonstrated in the inoculated cups, by the haemadsorption phenomenon. After $48 \mathrm{hr}$. incubation, the disks were removed and laid on Perspex plates with the tissue uppermost. The disks were covered with $0.1 \mathrm{ml}$. of a $0.5 \%(\mathrm{v} / \mathrm{v})$ suspension of washed chick erythrocytes in physiological saline, and the erythrocytes were allowed to sediment on to the tissue on the disks. After about half an hour, the disks were washed in a large beaker of physiological saline, mounted in glycerol, and examined under the microscope with phase-contrast illumination. In the controls, the erythrocytes were washed away in the beaker of saline, except for occasional single erythrocytes which remained in a few places. On the disks from the infected cups, clumps of erythrocytes could be seen still adherent to the tissue, particularly at the growing edges of the implanted fragments; an example is shown in Pl. 2, fig. 7. The haemadsorption again supported the view that the plasma gel was very thin and provided an insignificant barrier to contact with the tissue.

The effect of a strain of influenza virus on chick chorio-allantoic membrane. Chick allantoic fluid containing the PR8 strain of influenza A virus was diluted $10^{-2}$ and $0.02 \mathrm{ml}$. drops of this dilution were added to cups containing disks of freshly implanted fragments of chick chorio-allantoic membrane from 11-day eggs. Within $48 \mathrm{hr}$. incubation, lesions developed similar to those illustrated in Pl. 2, fig. 8, and when the disks, after incubation, were stained with ironhaematoxylin and examined with a $1 \cdot 6 \mathrm{~mm}$. objective, most of the cells within the lesion were seen to have shrunken nuclei and virtually no cytoplasm. Although the specificity of this lesion is not certain, it was not found in controls. Moreover, similar lesions were found when the chorion of an 11-day chick embryo was infected in situ with the same virus and squash preparations were made from the infected chorio-allantoic membrane removed from the egg after $48 \mathrm{hr}$. incubation.

\section{DISCUSSION}

The method of tissue culture described is intended as an analytical technique for selecting tissues which are infected, in some observable way, by a particular virus; it is not intended for adapted cell lines. Squashing the tissue gives rapid separation of cells without recourse to trypsin, and the architecture of the tissue is preserved. The squashed tissue is more easily examined microscopically and more readily infected than are fragments of tissue embedded in a 
plasma clot. Although tissue fragments can be squashed on to coverglasses instead of on to polythene, the thin sheet of cells does not remain adherent to the coverglass when using the technique described here. I have shown that tissue culture on polythene can be used for the study of a virus which produces cytopathic effects and for the study of another virus which can be detected by haemadsorption. An obvious extension is to use tissues derived from other embryos and so increase the range of viruses which can be studied. In appropriate cases, inclusion body stains could be used. Since polythene, unlike cellophan, does not fluoresce when exposed to ultraviolet radiation, a virus antigen could probably be detected by the fluorescent-antibody technique. Finally, it is possible to embed the tissue on a polythene disk in methacrylate, and so obtain a block which contains precisely orientated tissue for thin sections to be examined in the electron microscope.

I should like to thank Mr Z. Walc-Pokrzywnicki for his valuable technical help, and Mr J. Turner for making the tissue culture trays.

\section{REFERENCES}

Bukantz, S. C., Rein, C. R. \& Kent, J. F. (1946). Studies in complement-fixation. II. Preservation of sheep's blood in citrate dextrose mixtures (modified Alsever's solution) for use in the complement-fixation reaction. J. Lab. clin. Med. 31, 394.

Expert Committee on Influenza. First Report (1953). Tech. Rep. Wld Hlth Org. 64, 42.

Fazekas de St Groth, S. \& White, D. O. (1958). An improved assay for the infectivity of influenza viruses. J. Hyg., Camb. 56, 151.

Fulton, F. (1958). Abstracts of communications. 4th int. Congr. Biochem. Section 6, Cellular Biochemistry, 6-1.

Fulton, F. \& Armitage, P. (1951). Surviving tissue suspensions for influenza virus titration. J. Hyg., Camb. 49, 247.

LILLIE, R. D. (1954). Histopathologic Technique, 2nd ed. New York: The Blakiston Company Inc.

\section{EXPLANATION OF PLATES}

\section{Plate 1}

Fig. 1. (a) Glass tissue culture tray having sixteen cups with internal diameter of $1.375 \mathrm{~cm}$. (b) Polythene disks with a diameter of $1.25 \mathrm{~cm}$. and a thickness of $0.00375 \mathrm{~cm}$.

Fig. 2. Polythene disks squashed over tissue fragments on Perspex plate.

Plate 2

Fig. 3. Fragment of chick embryo lung immediately after implantation on polythene disk. Mounted on a microscope slide in glycerol and examined with phase-contrast illumination. $\times 160$.

Fig. 4. Fragments of chick embryo lung implanted on polythene disk and cultured at $37^{\circ}$ for $48 \mathrm{hr}$. Mounted in glycerol and examined with phase-contrast illumination. $\times 160$.

Fig. 5. Preparation as in fig. 4, but stained with Heidenhain's iron-haematoxylin and mounted in balsam. Examined with phase-contrast illumination. $\times 1000$.

Fig. 6. Fragments of chick embryo lung implanted on polythene disk and immediately infected with a $10^{-4}$ dilution of mouse brain containing Semliki forest virus. Cultured at $37^{\circ}$ for $48 \mathrm{hr}$. to show the cytopathogenic effect. Mounted in glycerol. $\times 160$. 
Fig. 7. Fragments of chick embryo lung implanted on polythene disk and immediately infected with a $10^{-2}$ dilution of chick allantoic fluid containing the PR8 strain of influenza A virus. Cultured at $37^{\circ}$ for $48 \mathrm{hr}$. to show the haemadsorption phenomenon. Mounted in glycerol. $\times 160$.

Fig. 8. Fragments of 11-day chick embryo chorio-allantoic membrane implanted on polythene disk and immediately infected with a $10^{-2}$ dilution of chick allantoic fluid containing the PR 8 strain of influenza A virus. Incubated at $37^{\circ}$ for $48 \mathrm{hr}$. to show what may be a specific virus lesion. Stained with Heidenhain's iron-haematoxylin. $\times 160$.

(Received 24 August 1959) 
Jourmal of Cieneral Microbiology, l'ol. 22, No.2
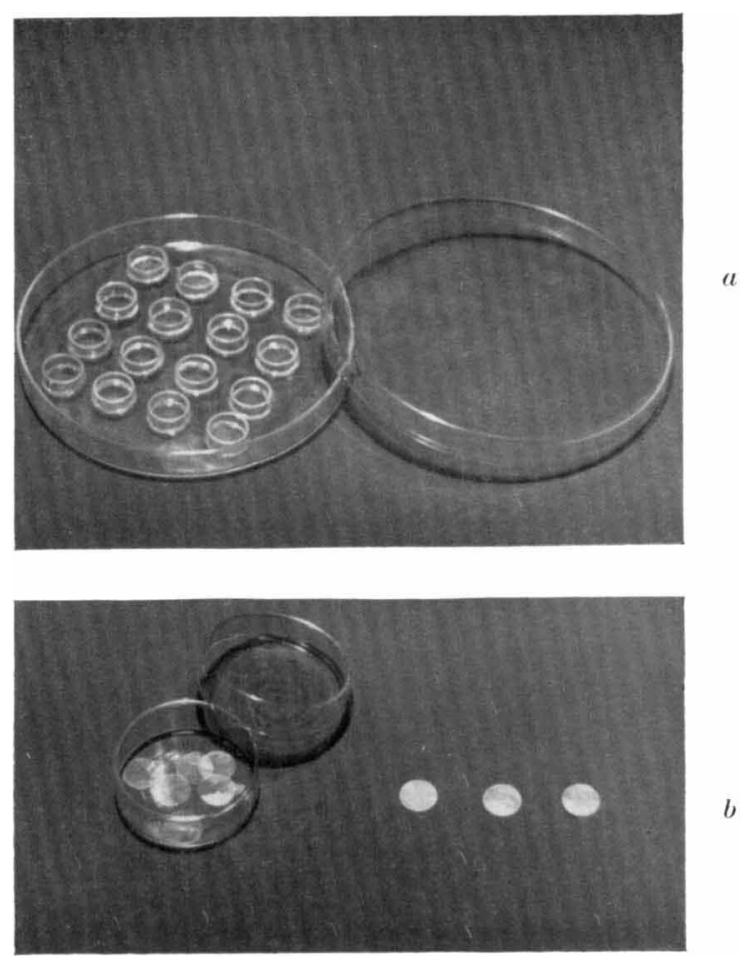

lig. 1

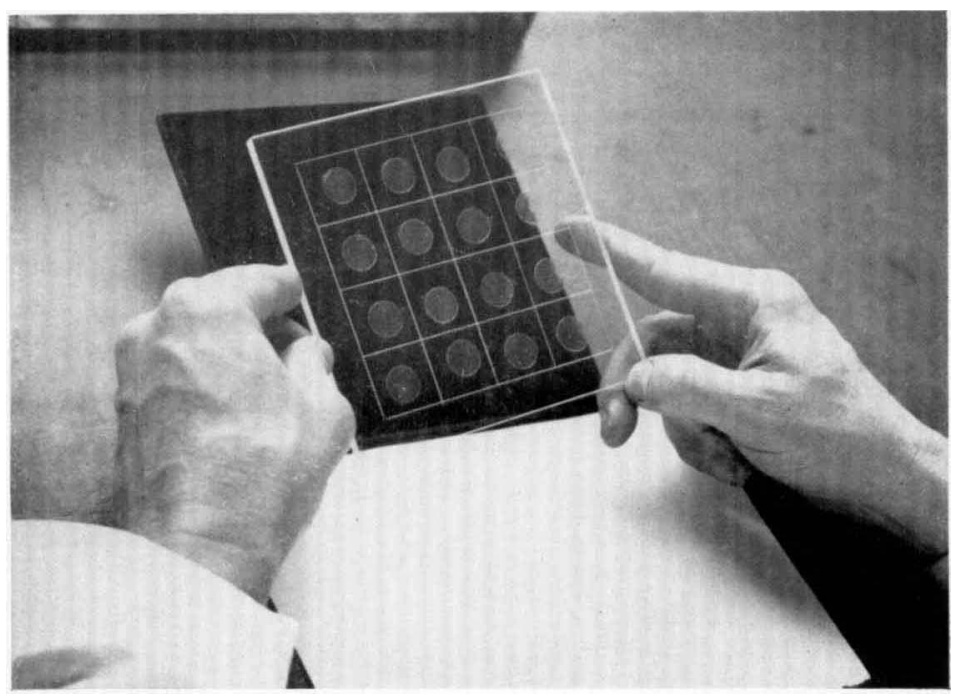

Fin. :2

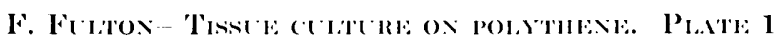


Journal of General Microbiology, Vol. 22, No. 2
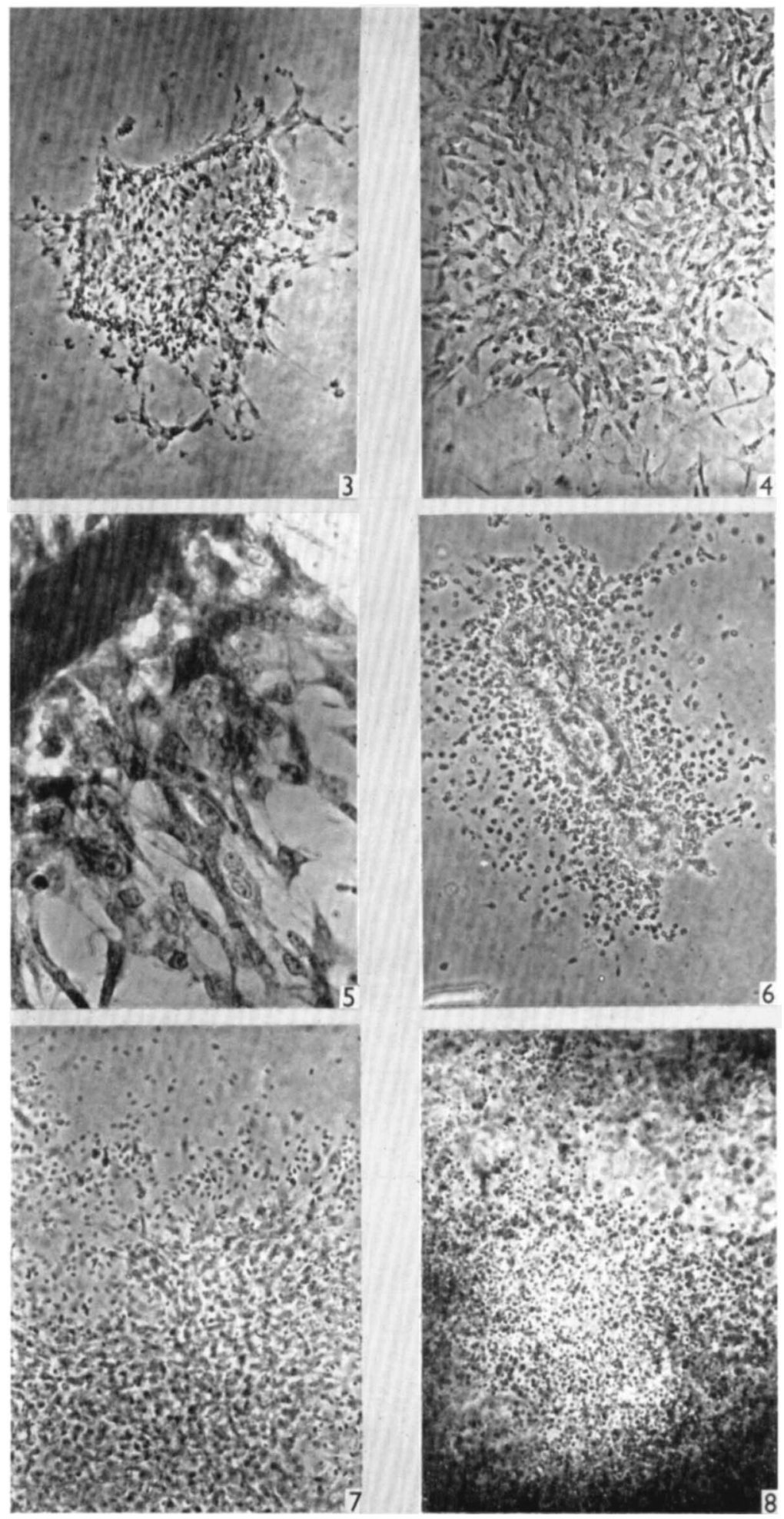

F. Fulton-'Tissce culture on polythene. Plate 2 